\title{
The Fifth Amendment at Justice: A Reply
}

Stephen J. Schulhofert

Mr. Markman's response to "Reconsidering Miranda" misses the article's central point, which was to offer a theory of fifth amendment compulsion and to consider the legitimacy of Miranda within the framework of that theory. Mr. Markman has no theory, and he makes no effort to explain why mild pressures and small financial penalties sometimes constitute compulsion. He invites us to treat police interrogation as a category unto itself and to hold permissible some pressures that would be found compelling outside the custodial setting. He declines even to consider whether his less protective notion of compulsion is justified by differences in context, though his reason for avoiding comparisons becomes clear when we spell out those differences. In police interrogation, the suspect is cut off from communication with any lawyer, friend, or neutral observer. Questioned in a threatening environment by those who hold him physically under their control, the suspect "is painfully aware that he literally cannot escape a persistent custodial interrogator."

While Markman offers no affirmative theory of what compulsion means, we can learn a good deal from his discussion of what compulsion does not mean. One theory, that compulsion requires a formal obligation backed by sanctions, was a mainstay of pre-Miranda arguments that the privilege against self-incrimination was irrelevant to police interrogation. Markman agrees with me that Miranda's rejection of this theory was "obviously correct" (p. 939). ${ }^{2}$ Another candidate is the theory that compulsion requires "physical violence or other deliberate means calculated to break the suspect's will."3 Again Markman agrees that my rejection of

† Frank and Bernice J. Greenberg Professor of Law and Director of the Center for Studies in Criminal Justice, The University of Chicago.

'Minnesota v. Murphy, 465 U.S. 420, 433 (1984).

2 All parenthetical page references are to Stephen J. Markman, The Fifth Amendment and Custodial Questioning: A Response, 54 U. Chi. L. Rev. 938 (1987) (this issue), commenting on Stephen J. Schulhofer, Reconsidering Miranda, 54 U. Chi. L. Rev. 435 (1987) ("Schulhofer").

${ }^{3}$ Oregon v. Elstad, 470 U.S. 298, 312 (1985). 
this view is "obviously correct" (p. 939). Yet it was precisely this theory that the Supreme Court invoked to find an absence of compulsion in Elstad, Tucker, and Quarles. ${ }^{4}$ Markman evidently agrees with me that the analytical premise of those cases is "obviously [in]correct."

Why, then, does Markman challenge the view of compulsion offered in Miranda and in my article? The historical materials cannot bear the weight Markman places upon them. He emphasizes that preliminary examinations of suspects had been "a basic feature of criminal procedure [since the sixteenth century] and remained so until the mid-nineteenth century" (p. 942). But his own sources stress that the preliminary examination of the sixteenth and seventeenth centuries relied upon compulsory process and often upon torture. ${ }^{5}$ The existence of such practices casts no doubt on my claim that the fifth amendment was intended to prohibit "pretrial examination by magistrates . . . under formal process" or other compulsion. ${ }^{6}$ Moreover, mid-nineteenth-century willingness to tolerate "aggressive" interrogation, with no warnings and no right to avoid questioning (p. 941), is not helpful in interpreting the intended content of fifth amendment "compulsion." Turning again to Markman's own sources, we find that such practices were either perceived as contrary to the privilege or were reconciled with it on the sole ground (properly rejected by Markman) that compulsion required a formal obligation to respond. ${ }^{7}$

Markman dismisses as a creature of "late-nineteenth-century statutory developments" the defendant's free choice whether to testify at his trial (p. 940). Under Markman's approach, the criminal defendant would be in the same position as a witness who is not a criminal suspect: at trial he would have "no [constitutional]

- Id.; Michigan v. Tucker, 417 U.S. 433, 443-46 (1974); New York v. Quarles, 467 U.S. 649,654 (1984).

- See E. M. Morgan, The Privilege Against Self-Incrimination, 34 Minn. L. Rev. 1, 18 (1949).

- Schulhofer at 438 (emphasis added).

7 The New York practice, for example, is colored by the fact that New York did not adopt a privilege against self-incrimination until the mid-nineteenth century; some authorities describe the New York courts of the earlier period as "indifferen[t]" to the privilege. See Morgan, 34 Minn. L. Rev. at 22-23 \& n.88 (cited in note 5). Markman's reliance on Mayers is similarly problematic. Mayers explains:

[I]t was considered entirely consistent with [the fifth amendment] for the committing magistrate to question the prisoner. . . [ [He was] not required to swear to tell the truth and [was] not punishable for refusing to answer. . . . [B]eing threatened neither with a prosecution for perjury nor with one for contempt, he could not be said to be "compelled" to be a "witness against himself."

Lewis Mayers, Shall We Amend the Fifth Amendment? 223-24 (1959). 
right to prevent questioning and may be presented with very substantial incentives to respond" (p. 940). The nearly universal understanding of the fifth amendment is diametrically opposed to this view. ${ }^{8}$

Markman thinks that the practice of questioning under subpoena a targeted grand jury witness or suspected accomplice is evidence against my claim that any pressure "imposed for the purpose of discouraging the silence of a criminal suspect constitutes prohibited compulsion" (p. 939)..$^{9}$ But as he knows, such a witness cannot be "required to answer over his valid claim of the privilege." 10 The right to claim the privilege could hardly arise if such a witness were not facing "compulsion."

Miranda requires that once a suspect does claim the privilege, all questioning must cease. Markman considers this rule anomalous because he assumes that outside the custodial context, the fifth amendment gives witnesses "no right to prevent questioning" (p. 940). The fact that the fifth amendment sometimes provides more protection in custodial interrogation than elsewhere should not be surprising, in light of the unusual vulnerability of the suspect in custody. ${ }^{11}$ But in regard to the right to prevent questioning, Markman's assumption about the rule applied in noncustodial settings is mistaken. When further questioning is permitted after a witness invokes the privilege, it is usually because the witness, if he is not the focus of the investigation, will have no privilege with respect to subsequent, non-incriminating questions. With respect to potentially incriminating questions, Markman's claim that a witness "validly asserting the fifth amendment right . . . has no right to prevent further questioning" (p. 940 n.5) is simply incorrect. Namet $v$. United States, which he cites in support of that proposition, says precisely the opposite. ${ }^{12}$ And in informal, noncus-

${ }^{8}$ See, e.g., Carter v. Kentucky, 450 U.S. 288, 302 (1981).

${ }^{9}$ Quoting Schulhofer, 54 U. Chi. L. Rev. at 445 (cited in note 2).

10 Murphy, 465 U.S. at 427.

11 Id. at 433.

12373 U.S. 179 (1963). In Namet, the prosecutor questioned two witnesses (Mr. and Mrs. Kahn) about certain matters relating to the defendant, even though their counsel had warned that the Kahns would claim the privilege against self-incrimination. The Court affirmed the conviction, but its opinion in no way suggested that continued questioning of the Kahns had been proper. On the contrary, the decision rested on the facts that the prosecutor properly planned to question them about unprivileged matters, that very few questions touched on privileged areas, that the defense had failed to object, and that there was little, if any, prejudice. The Court wrote:

In the course of eliciting this and other relevant [nonprivileged] testimony, the prosecutor asked only four questions held to be privileged. We cannot find that these few lapses, when viewed in the context of the entire trial, amounted to planned or deliber- 
todial interviews, a witness who asserts the fifth amendment can prevent further questioning by simply invoking his right to walk away.

Markman's refusal to recognize any "right to prevent questioning" leads him to find no constitutional violation in Edwards $v$. Arizona (pp. 947-48). ${ }^{13}$ The defendant there invoked his privilege and refused to submit to questioning, but a sheriff told him that he "had to." Chief Justice Burger wrote that "[t]his is enough for me,"14 but it would not be enough under Markman's unstated theory of compulsion. Proscribed compulsion apparently must be more than persistent, unwanted questioning, more than use of "the threat of criminal punishment . . . 'for the purpose of discouraging ... silence" " (p. 939), ${ }^{18}$ and more than "very substantial incentives to respond" (p. 940), but it need not "break the will." Markman's essay, like the Justice Department's 120-page report, nowhere suggests how to walk this constitutional tightrope.

Even under an acceptable theory of compulsion, not every unwarned custodial statement is compelled. My article explains when the Court's constitutional role permits (and sometimes requires) adoption of an irrebuttable presumption and why police interrogation without warnings calls for an irrebuttable presumption of compulsion. Markman emphatically rejects my conclusions. But he does not confront my arguments or examples. Since he regards irrebuttable presumptions in constitutional law as invariably illegitimate, he could find nothing automatically compelling about 36 hours of continuous interrogation or questioning accompanied by a few slaps or kicks. And this decision principle would join a substantive standard that allows "very substantial" incentives to discourage silence and denies the suspect any right to cut off questioning. The practical impact of that approach makes it easy to see why, just last year, Justice O'Connor wrote for the Court that "the [Miranda] decision as written strikes the proper balance between

ate attempts by the Government to make capital out of witnesses' refusals to testify. We are particularly reluctant to fasten such motives on the Government's conduct when, as here, defense counsel not only failed to object on behalf of the defendant, but in many instances actually acquiesced in the procedure as soon as the rights of the witnesses were secured. Nor can we find that the few invocations of privilege by the Kahns were of such significance in the trial that they constituted reversible error even in the absence of prosecutorial misconduct. The effect of these questions was minimized by the lengthy nonprivileged testimony which the Kahns gave.

373 U.S. at 189 (emphasis added).

is 451 U.S. 477 (1981).

14 Id. at 488 (concurrence).

${ }^{16}$ Quoting Schulhofer, U. Chi. L. Rev. at 445 (cited in note 2). 
society's legitimate law enforcement interests and the protection of the defendant's Fifth Amendment rights."16

Markman's renewed claims about damage to law enforcement do nothing to bolster the weaknesses of his office's original report. The "calculating criminal who eagerly enters into conversations with the police ... [and] the contrite criminal who freely gives a full confession" (p. 942) will continue to do so after being warned of their rights. Some suspects who thought themselves obliged to respond will not talk after receiving warnings, and so the confession rate presumably will fall. But fewer confessions (a consequence of the fifth amendment that the framers undoubtedly anticipated) damage law enforcement only if other, equally persuasive evidence of guilt is unavailable. Apparently, this is seldom the case because, as my article stressed, falling confession rates have not significantly reduced clearance and conviction rates. ${ }^{17}$ In addition, more careful investigation (spurred on by $\mathrm{Mi}$ randa's limits on interrogation) sometimes produces even stronger evidence. For these reasons, support for Miranda runs high even in the law enforcement community, and news stories about police reaction to the Justice Department report have carried such headlines as "Police Chiefs Defend Miranda Against Meese Threats" and "Ed Meese's War on Miranda Draws Scant Support."18

Markman chides me for not spelling out my methodological criticisms of the New York and Philadelphia studies that purport to show damage to law enforcement. The weaknesses of the New York study are transparent. A summary of its findings states that 49 percent of defendants confessed before Miranda and only 15 percent afterwards, but in fact the study tabulated only the number of confessions "used in presenting cases to [the] grand jury," not the number of confessions obtained. ${ }^{19}$ Although confessions

${ }_{18}$ Moran v. Burbine, 106 S.Ct. 1135, 1143 (1986). Markman suggests (p. 943) that Miranda's irrebuttable presumption theory was rejected by the Court in Elstad, 470 U.S. at 306-07 n.1. Markman's reliance on this passage is unfathomable. The cited footnote stresses the Court's approval of the irrebuttable presumption concept: "A Miranda violation does not constitute coercion but rather affords a bright-line, legal presumption of coercion, requiring suppression of all unwarned statements."

${ }^{17}$ See authorities cited in Schulhofer at $456 \mathrm{nn} .52-54,457-58 \mathrm{nn} .58-59,54$ U. Chi. L. Rev. "cited in note 2". Markman correctly cautions that conviction rates alone cannot provide an airtight measure of Miranda's law enforcement impact (p. 946-47 n.20). I noted the same caveat in my article. See Schulhofer, $54 \mathrm{U}$. Chi. L. Rev. at $458 \mathrm{n} .59$ (cited in note 2). But when conviction rates, clearance rates, and the impressions of law enforcement officers in the field are considered together, a reasonably reliable picture emerges.

${ }^{18}$ See Schulhofer, 54 U. Chi. L. Rev. at 456 n.53 (cited in note 2).

19 Controlling Crime Through More Effective Law Enforcement: Hearings Before the Subcomm. on Criminal Laws and Procedures of the Senate Comm. on the Judiciary, 90th 
"could be presented"20 in only 15 percent of the post-Miranda cases, this figure is readily explained by Miranda's partial retroactivity, which prevented use of nearly all pre-Miranda confessions in the immediate post-Miranda period. ${ }^{21}$

The shortcomings of the Philadelphia study, though less obvious, have long been well-documented:22 it did not cover all arrestees and did not explain its sampling procedure; the police did not record the number of suspects who gave statements but only those who refused:23 and the study took no account of changing arrest patterns, which rendered its conclusions "speculative."24 When Markman asks us to believe that those who deny Miranda's damage to law enforcement-including Chief Justice Warren Burger, Justice Tom Clark, FBI Director Clarence Kelly, Republican Senator Arlen Specter, and the chief of police in Pittsburgh ${ }^{25}$-are blinded by "ideological affinities for Miranda" (p. 8), we are entitled to be skeptical.

Markman's final claim is that overruling Miranda would pave the way for "far more effective protection" for the suspect (p. 9). Of course, the Miranda opinion emphasizes that an equally effective legislative solution would be an acceptable substitute for its approach. ${ }^{26}$ Thus, Markman remains free to pursue reform without seeking Miranda's demise as a prerequisite. His real objective, stated candidly in his office's report, is not to give suspects "far more effective protection" but rather to assail Miranda's "symbolic status" and to "repudiate [the] discredited criminal jurisprudence" of the Warren Court. ${ }^{27}$ While Markman correctly observes that for

Cong., Ist Sess. at 1120 (1967) (statement of Frank Hogan, former New York County District Attorney).

${ }^{20}$ Id. (emphasis added).

${ }^{21}$ Markman attempts to paper over this fatal defect in the New York study; he asks us to assume that prosecutors presented the inadmissible confessions to the grand jury because federal decisions would not have prevented them from doing so (p. 946 n. 19). But the New York rules applicable in 1966 clearly provided that "[t]he grand jury can receive none but legal evidence." N.Y. Code Crim. Pro. § 249 (1958) (superseded by N.Y. Crim. Pro. Law $\S 190.30(1)$, effective Sept. 1, 1971). See People v. Fleischmann, 250 N.Y.S.2d 660 (Sup. Ct. 1964) (dismissing indictment that rested on inadmissible confession).

${ }^{22}$ See Harold E. Pepinsky, A Theory of Police Reaction to Miranda v. Arizona, 16 Crime \& Delinquency 379, $382-83$ (1970).

${ }^{23}$ Refusal rates may have risen because more suspects were asked (perhaps perfunctorily) to give statements.

24 Pepinsky, 16 Crime \& Delinquency at 383 (cited in note 22).

${ }^{23}$ See Schulhofer, 54 U. Chi. L. Rev. at $456-58 \&$ n.59 (cited in note 2).

28384 U.S. 436, 467 (1966).

${ }^{27}$ U.S. Department of Justice, Office of Legal Policy, Report to the Attorney General on the Law of Pre-trial Interrogation 115 (Feb. 12, 1986). 
the past 20 years legislatures have been unwilling to enact interrogation reforms with Miranda on the books, the experience of the previous 150 years shows that such reforms will not occur without a decision like Miranda.

Markman deserves credit for closing his article with a discussion of the right issue - the need for effective protection of the suspect. Unfortunately, after giving so much attention to problematic evidence of damage to law enforcement, he gives none to the dramatic, well-documented evidence of interrogation violence that persists to this day. ${ }^{28} \mathrm{~A}$ particularly horrifying example was reported in recent weeks by the Illinois Supreme Court. ${ }^{29}$ Of course, I know that Markman does not approve of police brutality, and that it would remain illegal even without Miranda. But Miranda is not irrelevant to the incidence of serious physical abuse. Brutal interrogation tactics persist even under a regime that forcefully instructs officers to cease questioning whenever the suspect invokes his right to silence. What would occur if officers were told that it was legal (and perhaps therefore their duty) to use all pressures short of actually "breaking the will," or if they were told, in Markman's formulation, that the suspect has no right to prevent interrogation and can be subjected to "aggressive" questioning with "very substantial incentives to respond"?

Miranda is not only sound as a matter of the fifth amendment concept of compulsion. Miranda remains a crucial tool for safeguarding the dignity and physical safety of the suspect, a goal that police administrators and responsible Justice Department officials surely share.

${ }^{28}$ See Schulhofer, 54 U. Chi. L. Rev. at 448 n.26 (cited in note 2).

${ }^{28}$ People v. Wilson, 116 Ill.2d 29 (1987) (suspect, severely beaten and bound to radiator, suffered second-degree burns, numerous contusions, and injury to one eye). 